\title{
Prevalence of Functional Limitation in COVID-19 Recovered Patients Using the Post COVID-19 Functional Status Scale
}

\author{
Pankaj Pant, ${ }^{1}$ Aishana Joshi, ${ }^{2}$ Babin Basnet, ${ }^{3}$ Bibek Man Shrestha, ${ }^{3}$ Navindra Raj Bista, ${ }^{4}$ Niraj Bam, ${ }^{1}$ Santa \\ Kumar Das ${ }^{1}$ \\ 'Department of Pulmonology and Critical Care, Tribhuvan University Teaching Hospital, Maharajguni, Kathmandu, \\ Nepal, ${ }^{2}$ Department of General Practice and Emergency Medicine, Tribhuvan University Teaching Hospital, \\ Maharajguni, Kathmandu, Nepal, ${ }^{3}$ Maharajguni Medical Campus, ${ }^{4}$ Department of Anaesthesiology, Tribhuvan \\ University Teaching Hospital, Institute of Medicine, Maharajgunj, Kathmandu, Nepal.
}

\begin{abstract}
Introduction: COVID-19 is an emerging global health pandemic causing tremendous morbidity and mortality worldwide. Chronic symptoms progressing to poor functional status have been reported in a substantial proportion of COVID-19 patients worldwide. This study aimed to determine the prevalence of functional limitation in COVID-19 recovered patients using the post-COVID-19 functional status scale.
\end{abstract}

Methods: A descriptive cross-sectional study was conducted at Tribhuvan University Teaching Hospital. COVID-19 recovered patients with reverse transcription-polymerase chain reaction negative status were included and assessed using the post-COVID-19 functional status scale. Data entry and analysis was done in Statistical Package for the Social Sciences version 20.0. Descriptive statistics were performed.

Results: A total of 106 patients were included for the final analysis. More than half of the patients $(56.6 \%)$ reported having no functional limitation (grade 0 ), while the prevalence of some degree of functional limitation was observed in $46(43.4 \%)$ patients (grade 1 to 4 ).

Conclusions: Some form of functional limitation should be anticipated after COVID-19 infection. Post-COVID-19 functional status scale can be a valuable tool in determining the prevalence of functional limitation in COVID-19 recovered patients in acute health care settings. It can potentially guide in planning rehabilitative measures in post-acute care management of COVID-19 survivors.

Keywords: COVID-19; functional status; PCFS scale.

\section{INTRODUCTION}

Coronavirus disease 2019 (COVID-19) is caused by severe acute respiratory syndrome coronavirus-2 (SARS-COV-2). The first outbreak of SARS-COV2 was reported in Wuhan, Hubei Province in China. ${ }^{1}$ It was declared a global pandemic by the World Health Organization (WHO). ${ }^{2}$ The first confirmed case of COVID-19 from Nepal was reported in January 2020. ${ }^{3}$

A wide range of pulmonary and extra-pulmonary manifestations have been reported in post-COVID-19 patients. ${ }^{4-6}$ Persisting symptoms with subsequent progression to poor functional status have been reported in a substantial proportion of these patients. Acute respiratory distress syndrome (ARDS), prolonged hospitalization, and admission in an Intensive Care Unit (ICU) have been reported among
COVID-19 infections in acute care settings. ${ }^{7,8}$ The physical and mental health assessment in COVID-19 survivors with emphasis on post-acute care has been a recent global health concern.

This study aims to determine the prevalence of functional limitation in COVID-19 recovered patients using the post COVID-19 functional status (PCFS) scale. $^{9}$

\section{METHODS}

This is a descriptive cross-sectional study conducted in the department of Pulmonology and Critical Care

Correspondence: Dr. Pankaj Pant, Department of Pulmonology and Critical Care, Tribhuvan University Teaching Hospital, Institute of Medicine, Maharajgunj, Kathmandu, Email: drpant2015@gmail.com, Phone: +977-9851110939. 
Pant et al. Prevalence of Functional Limitation in COVID-19 Recovered Patients Using the Post COVID-19 Functional Status Scale

at Tribhuvan University Teaching Hospital (TUTH) in December 2019. Ethical approval was taken from Institutional Review Committee, TUTH (Reference no. 152/(6-11)/E2/077/078 dated December 8, 2020). The sample size was calculated as follows:

Samples size $=\mathrm{n}$

Confidence level $(\mathrm{Cl})=95 \%$,

For $95 \% \mathrm{Cl}$, Z-score $(\mathrm{Z})=1.96$

Level of significance $=5 \%$

Sampling error $(e)=10 \%$

Prevalence for maximum sample size $(p)=50 \%$

$\mathrm{n}=\mathrm{Z}^{2} \mathrm{pq} / \mathrm{e}^{2}$

$=(1.96)^{2} \times 0.5 \times(1-0.5) /(0.1)^{2}$

$=96.04$

$\approx 96$

Taking $10 \%$ non-response rate in the calculated sample size $=9.6$

Hence, minimum sample size $=96.04+9.6=105.64 \approx 106$

A convenient sampling technique was used. COVID-19 survivors with RT-PCR negative status were included in the study. Patients with active COVID-19 infection, known cardiac and/or respiratory co-morbidities with Medical Research Council (MRC) grade $>0$ and $\mathrm{New}$ York Heart Association (NYHA) grade $>1$ were excluded from the study. Patients with known functional disabilities and known illness likely to progress and limit physical ability like trauma, malignancies, progressive myopathies, and neuropathies were excluded from the study.

A total of 106 patients were included for the final analysis. The functional limitations were observed using the post-COVID-19 functional status (PCFS) scale (Table 1). ${ }^{9}$

\begin{tabular}{|c|c|c|}
\hline $\begin{array}{l}\text { How much are you currently affected in your everyday life } \\
\text { by COVID-19 (Please indicate which one of the following } \\
\text { statements applies to the most) }\end{array}$ & $\begin{array}{l}\text { Corresponding } \\
\text { PCFS scale } \\
\text { grade }\end{array}$ & Interpretation \\
\hline $\begin{array}{l}\text { I have no limitations in my everyday life and no symptoms, } \\
\text { pain, depression or anxiety related to the infection. }\end{array}$ & 0 & No functional limitations \\
\hline $\begin{array}{l}\text { I have negligible limitations in my everyday life as I can } \\
\text { perform all usual duties/activities, although I still have } \\
\text { persistent symptoms, pain, depression or anxiety. }\end{array}$ & 1 & Negligible functional limitations \\
\hline $\begin{array}{l}\text { I suffer from limitations in my everyday life as I occasionally } \\
\text { need to avoid or reduce usual duties/activities or need to } \\
\text { spread these over time due to symptoms, pain, depression or } \\
\text { anxiety. I am, however, able to perform all activities without } \\
\text { any assistance. }\end{array}$ & 2 & Slight functional limitations \\
\hline $\begin{array}{l}\text { I suffer from limitations in my everyday life as I am not able } \\
\text { to perform all usual duties/activities due to symptoms, pain, } \\
\text { depression or anxiety. I am, however, able to take care of } \\
\text { myself without any assistance. }\end{array}$ & 3 & Moderate functional limitations \\
\hline $\begin{array}{l}\text { I suffer from severe limitations in my everyday life: I am not } \\
\text { able to take care of myself and therefore I am dependent on } \\
\text { nursing care and/or assistance from another person due to } \\
\text { symptoms, pain, depression or anxiety. }\end{array}$ & 4 & Severe functional limitations \\
\hline
\end{tabular}

Patients were graded from 0 to 4 according to the PCFS scale. The patients falling in all grades except grade 0 were observed to have some degree of functional limitation, which was further graded from 1 to 4 into negligible, slight, moderate, and severe groups depending on the severity of functional limitation (Table 1). Data were obtained using a semistructured questionnaire self-reported by the patients. Data entry and analysis was done in SPSS version 20.0. Descriptive statistics were performed, and results were interpreted in frequency and percentage.

\section{RESULTS}

A total of 106 patients with RT-PCR negative status were included for final analysis. The mean age of patients was $38.48 \pm 16.20$ years, with a range from 22 to 83 years. The highest number of patients was 15-29 years in both sexes (Table 1). 
Pant et al. Prevalence of Functional Limitation in COVID-19 Recovered Patients Using the Post COVID-19 Functional Status Scale

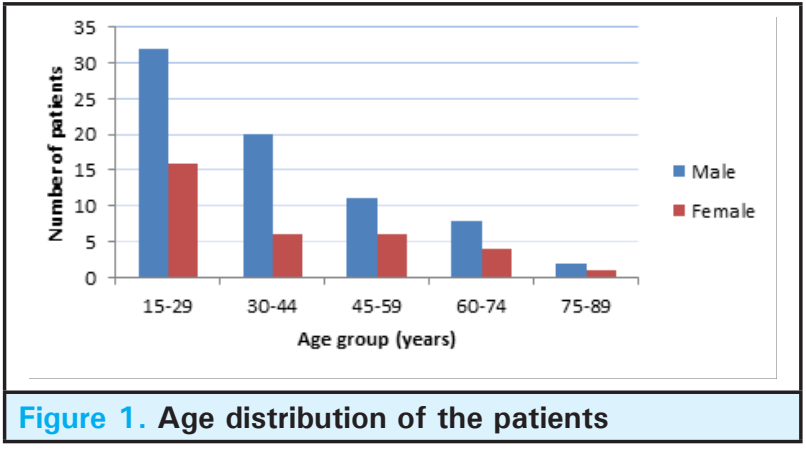

There were $73(68.9 \%)$ males and $33(31.1 \%)$ females. Nearly half of the patients $(47.2 \%)$ were health care workers who comprised doctors $(26.4 \%)$, nurses $(12.3 \%)$, and paramedical staff (8.5\%). Hypertension was the most common co-morbidity seen in 20 (18.9\%) patients, followed by Diabetes mellitus in 15 (14.2\%) patients. Seventeen percent of these patients required hospital admission during COVID-19 infection (Table1).

\begin{tabular}{|ll|}
\hline \multicolumn{2}{|l|}{ Table 2. Baseline characteristics of the patients } \\
(n=106). & $\mathrm{n}(\%)$ \\
\hline Characteristics & \\
Sex & $73(68.9)$ \\
Male & $33(31.1)$ \\
Female & \\
Residence & $67(63.2)$ \\
Kathmandu valley & $39(36.8)$ \\
Outside Kathmandu valley & \\
Health care workers & $50(47.2)$ \\
Yes & $56(52.2)$ \\
No & \\
Occupation & $28(26.4)$ \\
Doctors & $13(12.3)$ \\
Nurses & $9(8.5)$ \\
Paramedics & $15(14.2)$ \\
Students & $6(5.7)$ \\
Business & $19(17.9)$ \\
Service & $7(6.6)$ \\
Dependent & $9(8.5)$ \\
Others & \\
Cigarette smoking & $12(11.3)$ \\
Current smoker & $23(21.7)$ \\
Past smoker & $71(67)$ \\
Never smoked & \\
Co-morbidities & $66(62.3)$ \\
None & $20(18.9)$ \\
Hypertension & $15(14.2)$ \\
Diabetes mellitus & $8(7.5)$ \\
Post Tuberculosis (TB) sequelae & $6(5.7)$ \\
COPD & $5(4.7)$ \\
Thyroid disorder & $3(2.8)$ \\
Asthma &
\end{tabular}

\begin{tabular}{|ll|}
\hline Vaccination & \\
BCG & $85(80.2)$ \\
Pneumococcal (within last 5 years) & $5(4.7)$ \\
Influenza (within last 1 year) & $14(13.2)$ \\
Need for hospitalization & \\
Yes & $18(17)$ \\
No & $88(83)$ \\
\hline
\end{tabular}

\begin{tabular}{|llc|}
\hline $\begin{array}{l}\text { Table 3. Grading of patients according to the Post } \\
\text { COVID-19 Functional Status (PCFS) scale }\end{array}(\mathbf{n}=106)$. \\
\hline $\begin{array}{l}\text { Post COVID-19 } \\
\text { functional status } \\
\text { scale grade }\end{array}$ & Interpretation \\
Grade 0 & $\begin{array}{l}\text { No functional } \\
\text { limitations }\end{array}$ & $60(56.6)$ \\
Grade 1 & $\begin{array}{l}\text { Negligible functional } \\
\text { limitations }\end{array}$ & $29(27.3)$ \\
Grade 2 & $\begin{array}{l}\text { Slight functional } \\
\text { limitations }\end{array}$ & $13(12.3)$ \\
Grade 3 & $\begin{array}{l}\text { Moderate functional } \\
\text { limitations }\end{array}$ & $2(1.9)$ \\
Grade 4 & $\begin{array}{l}\text { Severe functional } \\
\text { limitations }\end{array}$ & $2(1.9)$ \\
\hline
\end{tabular}

During the post-COVID-19 recovery state after RT-PCR negative status, more than half of the patients $(56.6 \%)$ reported having no functional limitation (PCFS grade $0)$, while the prevalence of some degree of functional limitation was observed in 46 (43.4\%) patients (Table $3)$.

The majority of patients $(89.6 \%)$ had at least one of the pulmonary or extra-pulmonary symptoms during COVID-19 infection. A minority (11\%) did not report any symptoms. Fever was the most predominant symptom observed in two-third of the patients $(n=70$, $66 \%)$ followed by cough in $59(55.7 \%)$ and fatigue in 48 (45.3\%) patients (Table 4).

\begin{tabular}{|ll|}
\hline $\begin{array}{l}\text { Table 4. Predominant symptoms during } \\
\text { infection }(\mathbf{n}=\mathbf{1 0 6}) \text {. }\end{array}$ \\
\hline $\begin{array}{l}\text { Predominant symptoms during COVID-19 } \\
\text { infection }\end{array}$ \\
Asymptomatic & $11(10.4)$ \\
Fever & $70(66)$ \\
Cough & $59(55.7)$ \\
Fatigue & $48(45.3)$ \\
Loss of smell & $45(42.5)$ \\
Loss of taste & $40(37.7)$ \\
Shortness of breath & $23(21.7)$ \\
Sore throat & $15(14.2)$ \\
Chest pain & $12(11.3)$ \\
Myalgia & $10(9.4)$ \\
Headache & $5(4.7)$ \\
Loose stool & $4(3.8)$ \\
Abdominal pain & $3(2.8)$ \\
Vomiting & $2(1.9)$ \\
\hline
\end{tabular}




\section{DISCUSSION}

We assessed 106 COVID-19 recovered patients with RT-PCR negative status using the post-COVID-19 functional status (PCFS) scale. PCFS scale is a simple tool developed recently by Klok FA et al. ${ }^{9}$ to monitor the course of symptoms and its impact on patients' functional status in COVID-19 survivors.PCFS scale covers the full spectrum of functional outcomes and focuses on both limitations in usual duties/activities and lifestyle changes in five scale grades ranging from 0 to 4 . Based on the PCFS scale, we observed that during the post-COVID-19 recovery state after RT-PCR negative status, more than half of the patients $(56.6 \%)$ reported having no functional limitation (PCFS grade 0 ) while the prevalence of some degree of functional limitation was observed in 46 (43.4\%) patients. Nearly one fourth $(27.3 \%)$ of the patients had negligible functional limitation (PCFS grade 1). Slight functional limitation (PCFS grade 2) was seen in 13 (12.3\%) patients. Moderate (PCFS grade 3 ) and severe functional limitations (PCFS grade 4) were observed in a minority of patients with an equal proportion of patients $(n=2$, $1.9 \%$ ) in each of these groups. We observed that more than $50 \%$ of our patients had no functional limitation with corresponding PCFS grade 0 . This could have been partly due to the inclusion of a higher number of younger patients in our study. The mean age of patients in our study was $38.48 \pm 16.20$ years, with the highest number of patients in the age group of 15-29 years in both sexes. Younger patients are reported to have a better outcome as compared to the frail elderly population after COVID-19 infection. ${ }^{10-12}$ Strict isolation protocols, as adapted widely across many countries in the management of COVID-19 patients in hospitals, patients' own residence or at COVID isolation centers, have resulted in a significant reduction of patient's mobility. ${ }^{13}$ This could be specifically implicated for the decline in functional status in COVID-19 patients during recovery state.

Nearly $90 \%$ of patients reported at least one of the clinical symptoms. Fever was the most predominant symptom observed in two-third of the patients (66\%) followed by cough (55.7\%). Shortness of breath and chest pain were other pulmonary symptoms observed in $21.7 \%$ and $11.3 \%$ of patients, respectively. Persisting symptoms with subsequent progression to poor functional status have been reported in a substantial proportion of COVID-19 survivors. ${ }^{14,15}$ Pulmonary function impairment ${ }^{16}$, mental health problems, ${ }^{17}$ and reduced quality of life ${ }^{18}$ to a various extent have been reported in COVID-19 patients. These factors could have a long term impact on physical, mental, social and cognitive health and well being of COVID-19 infected patients, causing a decline in functional status.

The long term consequences of COVID-19 may vary extensively among patients. In view of the massive number of COVID-19 survivors who require long-term follow-up, a simple, easy, reproducible, and costeffective tool would be vital for proper utilization of resources in post-acute care COVID-19 patients and guide rehabilitative measures. Klok FA et al. ${ }^{9}$ have recommended using the PCFS scale depending on local conditions in which it is implemented. We used this tool in our study as it is simple and inexpensive and hence, could be specifically beneficial in resourcepoor health care settings. We recommend large multicentre studies with a greater sample size to validate the PCFS scale as a tool for assessing long-term postCOVID-19 functional status in the Nepalese population.

\section{CONCLUSIONS}

The physical and mental health effects of SARS-COV2 infection should be anticipated in every COVID-19 patient. Early detection of functional decline with subsequent planning of rehabilitative measures is vital in post-acute care management of COVID-19 patients. PCFS scale is a simple tool in determining the prevalence of functional limitation in COVID-19 recovered patients in acute health care settings. We recommend large multi-centre studies with a longer duration of follow-up to validate the PCFS scale to assess long-term health effects and post COVID-19 functional status in the Nepalese population.

Conflict of Interest: None.

\section{REFERENCES}

1. Lu H, Stratton CW, Tang YW. Outbreak of pneumonia of unknown etiology in Wuhan, China: The mystery and the miracle. Journal of medical virology. 2020 Apr;92(4):401-2. [PubMed | Full Text | DOI]

2. WHO Director-General's opening remarks at the media briefing on COVID-19 - 11 March 2020 [Internet]. 2020. Available from: https://www.who.int/dg/speeches/ detail/who-director-general-s-opening-remarks-at-the-media-briefing-on-covid-19---11-march-2020. [Full Text]
3. Bastola A, Sah R, Rodriguez-Morales AJ, Lal BK, Jha R, Ojha HC, Shrestha B, Chu DK, Poon LL, Costello A, Morita K. The first 2019 novel coronavirus case in Nepal. The Lancet Infectious Diseases. 2020 Mar 1;20(3):279-80. [PubMed | Full Text | DOI]

4. Johnson KD, Harris C, Cain JK, Hummer C, Goyal H, Perisetti A. Pulmonary and extra-pulmonary clinical manifestations of COVID-19. Frontiers in Medicine. 2020 Aug 13;7:526. [PubMed | Full Text | DOI] 
5. Goërtz YM, Van Herck M, Delbressine JM, Vaes AW, Meys R, Machado FV, Houben-Wilke S, Burtin C, Posthuma R, Franssen FM, van Loon N. Persistent symptoms 3 months after a SARS-CoV-2 infection: the post-COVID-19 syndrome? ERJ open research. 2020 Oct 1;6(4). [ $\underline{\text { PubMed }}$ | Full Text | DOI]

6. Kamal M, Abo Omirah M, Hussein A, Saeed H. Assessment and characterization of post-COVID-19 manifestations. International Journal of Clinical Practice. 2020 Nov 3:e13746. [PubMed | Full Text $\mid \underline{\text { DOI] }}$

7. Tzotzos SJ, Fischer B, Fischer H, Zeitlinger M. Incidence of ARDS and outcomes in hospitalized patients with COVID-19: a global literature survey. Critical Care. 2020 Dec;24(1):1-4. [ubMed | Full Text | DOI]

8. Ferrando C, Suarez-Sipmann F, Mellado-Artigas R, Hernández M, Gea A, Arruti E, Aldecoa C, Martínez-Pallí G, Martínez-González MA, Slutsky AS, Villar J. Clinical features, ventilatory management, and outcome of ARDS caused by COVID-19 are similar to other causes of ARDS. Intensive care medicine. 2020 Dec;46(12):2200-11. [PubMed | Full Text | DOI]

9. Klok FA, Boon GJ, Barco S, Endres M, Geelhoed JM, Knauss S, Rezek SA, Spruit MA, Vehreschild J, Siegerink B. The Post-COVID-19 Functional Status scale: a tool to measure functional status over time after COVID-19. European Respiratory Journal. 2020 Jul 1;56(1). [라Med | Full Text [ DOI]

10. Chen T, Dai Z, Mo P, Li X, Ma Z, Song S, Chen X, Luo M, Liang K, Gao S, Zhang Y. Clinical characteristics and outcomes of older patients with coronavirus disease 2019 (COVID-19) in Wuhan, China (2019): a single-centered, retrospective study. The Journals of Gerontology: Series A. 2020 Apr 11. [Full Text | DOI]

11. Hewitt J, Carter B, Vilches-Moraga A, Quinn TJ, Braude P, Verduri A, Pearce L, Stechman M, Short R, Price A, Collins JT. The effect of frailty on survival in patients with COVID-19 (COPE): a multicentre, European, observational cohort study. The Lancet Public Health. 2020 Aug 1;5(8):e444-51. [PubMed | Full Text | DOI]

12. Chinnadurai $\mathrm{R}$, Ogedengbe $\mathrm{O}$, Agarwal $\mathrm{P}$, Money-Coomes S, Abdurrahman AZ, Mohammed S, Kalra PA, Rothwell N, Pradhan S. Older age and frailty are the chief predictors of mortality in COVID-19 patients admitted to an acute medical unit in a secondary care setting-a cohort study. BMC geriatrics. 2020 Dec;20(1):1-1. [ubMed | Full Text | DOI]

13. Belli S, Balbi B, Prince I, Cattaneo D, Masocco F, Zaccaria S, Bertalli L, Cattini F, Lomazzo A, Dal Negro F, Giardini M. Low physical functioning and impaired performance of activities of daily life in COVID-19 patients who survived hospitalisation. European Respiratory Journal. 2020 Oct 1;56(4). [uued | Full Text | DOI]

14. Goërtz YM, Van Herck M, Delbressine JM, Vaes AW, Meys R, Machado FV, Houben-Wilke S, Burtin C, Posthuma R, Franssen FM, van Loon N. Persistent symptoms 3 months after a SARS-CoV-2 infection: the post-COVID-19 syndrome? ERJ open research. 2020 Oct 1;6(4). [․ㅏbMed | Full Text | DOI]

15. Carfì A, Bernabei R, Landi F. Persistent symptoms in patients after acute COVID-19. Jama. 2020 Aug 11;324(6):603-5. [PubMed | Full Text | DOI]

16. Zhao YM, Shang YM, Song WB, Li QQ, Xie H, Xu QF, Jia JL, Li LM, Mao HL, Zhou XM, Luo H. Follow-up study of the pulmonary function and related physiological characteristics of COVID-19 survivors three months after recovery. E Clinical Medicine. 2020 Aug 1;25:100463. [Full Text | DOI]

17. Ma YF, Li W, Deng HB, Wang L, Wang Y, Wang PH, Bo HX, Cao J, Wang Y, Zhu LY, Yang Y. Prevalence of depression and its association with quality of life in clinically stable patients with COVID-19. Journal of affective disorders. 2020 Oct 1;275:145-8. [ PubMed | Full Text | DOI]

18. Chen KY, Li T, Gong F, Zhang JS, Li XK. Predictors of health-related quality of life and influencing factors for COVID-19 patients, a follow-up at one month. Frontiers in Psychiatry. 2020;11:668. [PubMed | Full Text | DOI] are included in the article's Creative Commons license, unless indicated otherwise in the credit line; if the material is not included under the Creative Commons license, users will need to obtain permission from the license holder to reproduce the material. To view a copy of this license, visit http://creativecommons.org/licenses/by/4.0/ 